COMUNICAÇÃO CIENTÍFICA

\title{
EFFECT OF PRESTORAGE CURING ON STORAGE LIFE, INTERNAL AND EXTERNAL QUALITIES OF SWEET ORANGE (Citrus sinensis) ${ }^{1}$
}

\author{
ABIOLA TITILOLA ABORISADE ${ }^{2} \&$ AYODEJI ADEYEYE AJIBADE 2
}

\begin{abstract}
Orange fruits from two seasons, in April and August 2006 representing late 2005 and early 2006 harvests respectively were cured in hot air at $36-37^{\circ} \mathrm{C}$ to $1 \%, 3 \%, 5 \%$ and $7 \%$ weight loss before storage at $28^{\circ} \mathrm{C}$ and $86 \%$ relative humidity $(\mathrm{RH})$. The fruits were observed for incidence of decay, further weight loss, juice content, firmness or softening of the peel, total soluble solids (TSS), pH, titratable acidity, and colour during storage. Curing reduced the incidence of decay. All control fruits were rotten by day 21 in August harvest while $22.5 \%$ of the control was rotten by day 56 in the April harvest. Storage life was extended beyond 56 days in fruits cured with 1,3,5 and 7\% in April harvest as there was no decay throughout, while decay incidence in August harvest was 88.9, 61.1, 22.2 and 31.3\% in 1, 3, 5 and 7\% respectively. Penicillium digitatum, Phytophthora sp., Alternaria citri and Collectotrichum gloeosporioides were among decay causing moulds detected. Control fruits lost more weight during storage than cured fruits did. Fruit rind hardening was more noticed in the control and those cured to $1 \%$ weight loss, especially from the April harvest. It was insignificant in other treatments in both trials. Titratable acidity, $\mathrm{pH}$, juice content and TSS were not affected by the treatment. Colour change to yellow was however retarded by curing. Curing to $5 \%$ weight loss was best for decay control and quality retention.
\end{abstract}

Index terms: Curing, weight loss, storage treatment quality, fruits.

\section{EFEITO DA CURA ANTES DO ARMAZENAMETO NO PRAZO DE CONSERVAÇÃO, QUALIDADES INTERNAS E EXTERNAS DA LARANJA DOCE (Citrus sinensis)}

\begin{abstract}
RESUMO- Frutos de laranjas de duas safras, de Abril e de Agosto de 2006 representando colheitas do final de 2005 e começo de 2006 respectivamente foram curados em ar quente a $36-37^{\circ} \mathrm{C}$ até a perda de peso de $1 \%$, $3 \%, 5 \%$ e $7 \%$ antes do armazenamento a $28^{\circ} \mathrm{C}$ e $86 \%$ de umidade relativa (UR). Os frutos foram observados quanto à incidência de apodrecimento, mais tarde perda de peso, conteúdo de suco, firmeza ou amolecimento da casca, sólidos solúveis totais (TSS), pH, acidez titúlavel, e coloração durante o armazenamento. A cura diminuiu a incidência do apodrecimento. Todos os frutos controles da colheita de Agosto estavam podres pelo dia 21 enquanto que $22.5 \%$ dos frutos controle da colheita de Abril estavam podres pelo dia 56 . O prazo de conservação foi estendido para mais de 56 dias em frutos curados com 1, 3, 5 e 7 \% na colheita de Abril, não havendo apodrecimento até então, enquanto a incidência de apodrecimento na colheita de Agosto foi de 88.9, 61.1, 22.2 e 31.3\% em 1, 3, 5 e 7\% respectivamente. Penicillium digitatum, Phytophthora sp., Alternaria citri e Collectotrichum gloeosporioides foram detectados entre os fungos causadores de apodrecimento. Os frutos controle perderam mais peso durante o armazenamento do que os frutos curados. O endurecimento da casca do fruto foi mais notado no controle e naqueles curados com perda de peso de $1 \%$, especialmente os da colheita de Abril. Foi insignificante nos demais tratamentos em ambos os ensaios. A acidez titúlavel, o pH, o conteúdo de suco e o TSS não foram afetados pelo tratamento.A mudança de cor para o amarelo foi contudo retardada pela cura. A cura com a perda de peso a 5\% foi a melhor para o controle do apodrecimento e retenção da qualidade do fruto.
\end{abstract}

Termos para indexação: Cura, perda de peso, tratamento para qualidade de armazenamento, frutos.

${ }^{1}$ (Trabalho 116-09). Recebido em: 10-05-2009. Aceito para publicaçaõ em: 02-06-2010.

${ }^{2}$ Department of Biology, Federal University of Technology, PMB 704, Akure, Ondo State, Nigeria. e.mail: biolabo2000@yahoo.com, ajibadeco@yahoo.com 
The major postharvest problem of citruses is decay by fungi. Specifically, the diseases of oranges (Citrus sinensis) include green-rot by Penicillium digitatum, blue-rot by Penicillium italicum especially at refrigeration temperatures, sour-rot by Geotrichum citri-aurantii, anthracnose by Colletotrichum gloeosporioides, stem-end rots by Diplodia natalensis and Phomopsis citri, and stem-end black rot by $\mathrm{Al}$ ternaria citri (ISMAIL; ZHANG 2004). Correct cool chain management has been reported to be essential for all fruits and vegetables. In Nigeria, adequate cool storage facilities are lacking and orange fruits are mostly transported, stored and marketed at ambient temperatures. Typical shelf life of the fruit in such circumstances is about 7 days and this limits the country's participation in international trade of the commodity.

The other methods of extending storage life of oranges include inoculum reduction by preharvest farm sanitation and fruit washing, use of chemicals, waxing, prestorage heat treatment, curing, and controlled or modified atmosphere storage. Heat treatment, apart from reducing decay, was also reported to alleviate some physiological disorders such as chilling injury in orange fruits and other citruses (RODOV et al., 1995; SCHIRRA et al., 1997, SAPITNITSKAYA et al., 2006). Heat treatment is usually done in hot water, vapour heat, hot air and recently by radio frequency (RF) heating (FALLIK et al., 1993; JACOBI et al., 1996; AFEK at al., 1999; BIRLA et al., 2004, 2006). Curing is holding fruit at temperatures and humidity conducive to wound healing and detrimental to pathogen attack and it is normally done at specific temperature and time. Curing and various other types of heat treatment offer advantage in being cheap and convenient without undesirable effects on eventual consumers. Hot air curing was earlier reported to be effective in controlling green and blue mould rots on orange fruits (NUNES et al., 2007). Even biological and chemical control of the green and blue moulds of oranges by the bacterium Pseudomonas glathei and sodium carbonate respectively was reported to have been enhanced by heat treatment (HUANG et al., 1995; PLAZA et al., 2004). Most reports however, indicate that curing of oranges is usually followed by cool storage (LANZA et al. 2000) but reports on storage at ambient temperature are uncommon. In addition, there is the problem of maintaining heating equipments for the long periods required because of frequent power cuts in Nigeria.

This study therefore seeks to assess the efficacy of postharvest hot air curing treatment of oranges to specific weight losses rather than for specified lengths of time, in reducing decay by moulds during subsequent storage at $28^{\circ} \mathrm{C}$. It also seeks to determine the effect of such treatment on internal and external quality attributes of orange fruits.

\section{Plant material}

Fruits of sweet orange of Ambersweet variety were harvested from the same tree taking care to avoid damage by impact. Mature fruits with green rind were selected for uniformity of size and colour. They were washed in $1.03 \%$ sodium hypochlorite solution and drained. The fruits were then divided into five lots of forty (40) fruits each and the lots were cured to different levels of weight loss.

\section{Treatment and Storage}

Curing was done with hot air at $37^{\circ} \mathrm{C}$ in a Gallenkamp oven to individual weight losses of 1 , 3,5 and $7 \%$. The desired percentage weight loss was obtained by periodically weighing samples of fruits during curing treatment. Control fruits were not exposed to heat at all. The fruits were then stored on wooden pallets in metal drying cabinet with limited ventilation at $28^{\circ} \mathrm{C}$ and $87 \pm 2 \%$ relative humidity.

\section{Assessment of Fruit Quality}

The incidence of decay was determined as the percentage of decayed fruits in a whole lot of treated fruits. Decay was identified as softening/ watery spots, discolouration, offensive odour and aggregation of fungal spores and mycelium on fruit surface. The types and agents of decay were identified according to Ismail and Zhang (2004).

Further weight loss was calculated as

$\%$ Weight loss $=\underline{\text { Cured weight }- \text { Current weight }} \times 100$ Cured weight

The juice content in a fruit was determined by extracting the juice in each fruit by using a manual juice extractor and the volume determined in a measuring cylinder. To determine total soluble solids content, a few drops of the juice were placed in a Japanese ATANGO hand refractometer and the total soluble solids (TSS) was measured in ${ }^{\circ}$ Brix. Titratable acidity of freshly extracted juice was determined as amount of citric acid

( $\mathrm{g} / 100 \mathrm{ml}^{-1}$ juice) by standard procedure. All determinations were done at 7-day intervals. The texture was determined by using a cone Penetrometer (ELE Model EL-240540; capacity 0-400x0.1mm) with $50 \mathrm{~g}$ weight permanently hung on its cone. The cone of the instrument was allowed to penetrate three different points on each fruit. The texture was 
recorded as depth of penetration in mm and converted to Newton $(\mathrm{N}) / \mathrm{cm}^{2}$. Stony fruits were described as those with rind hardening but no sign of decay.

The $\mathrm{pH}$ was determined using a JENWAY $\mathrm{pH}$ meter. Colour was ranked on a scale of 1 to 6 with 1 representing completely green and 6 for complete yellow. The experiments were done in two trials between April-June (dry season harvest) and August-October (rainy/wet season harvest) 2006 for late 2005 season and early 2006 seasons respectively.

Each treatment was replicated on five fruits and data obtained were subjected to analysis of variance and the means were separated by Fisher's Least Significant Difference (LSD) where significant differences occurred.

The incidence of fruit decay during storage decreased as a result of prestorage heat treatment. This was observed in both dry and wet season trials. It however decreased more in the dry season harvest than the wet season trial (Table 1). The cured fruits remained healthy throughout the 56 day storage period but by $35^{\text {th }}$ day, incidence of decay was $22.5 \%$ in control fruits which first showed signs of decay on day 14 in dry season batch. For the wet season fruits, $5.6 \%$ decay incidence was observed on the $14^{\text {th }}$ day and it increased to $72.2 \%$ by day 21 in fruits cured to $1 \%$ weight loss. Those cured to 3,5 and $7 \%$ weight loss had 5.6, 11.1 and $12.5 \%$ decay incidence respectively on the $28^{\text {th }}$ day. Ninety percent of the control fruits were rotten by the 14th day in the wet season batch and had reached $100 \%$ by day 21 (Table 1 ). The diseases observed in the control fruits in both batches and cured fruits in the August batch during storage were anthracnose by Colletotrichum gloeosporioides, black rot by Alternaria citri, brown rot by Phytophthora sp. and green mould by Penicillium digitatum. The moulds occurred irrespective of the level of curing treatment. The treatment that was most effective in controlling decay was curing to $5 \%$ weight loss.

Hardness (stoniness) of the rind was noticed in some fruits especially in the April (dry season) trial. The control had the greatest incidence of stoniness (Table 1) with $67.5 \%$ occurrence by day 56 . Stoniness appeared first on day 42 in fruits cured to $1 \%$ weight loss and it increased to $10 \%$ by day 49 in the April batch. Stoniness was observed in only $5.6 \%$ of the fruits cured to 1 and $5 \%$ weight loss by day 70 in the August (wet season) trial. The stony fruits were hard, leathery and slightly wrinkled in appearance.

There was a general fluctuation in weekly weight loss in cured fruits but it was less than that of control fruits on days $14,35,49$, and $56 . \mathrm{Cu}$ mulative weight loss during storage was highest in control fruits.
The juice content of fruits during storage was only significantly affected by curing treatment on days 35 and 42 of storage (Table 2). There was also only a slightly significant effect of curing on total soluble solids content of fruits (Table 3 ) but the TSS content generally increased with storage especially in the later days of storage. Cured fruits had less titratable acidity than the control fruits and acidity decreased with increased level of curing (Table 4).

Firmness measured as depth of penetration and force in Newton was initially higher in treated fruits than the control till day 35 but with longer storage, penetration of treated fruits was more than untreated (Table 5). There was significant difference in firmness between control and fruits cured to 1, 3,5 and $7 \%$ from day 7 . The control fruits were consistently harder to penetrate from day 42 , their rinds having become more hardened than cured fruits. Generally, rind hardness in all fruits increased during storage.

Fruits cured to the highest level of weight loss $(7 \%)$ degreened very slowly and had not reached stage 3 of colour development by day 49 . The control fruits on the other hand were almost completely yellow by day 28 . The higher the level of curing treatment, the slower the fruits turned yellow. Peel colour change to yellow was retarded by treatment and fruits cured to $7 \%$ did not go beyond stage 4 even on day 56 . The $\mathrm{pH}$ of fruits was between 4.99 and 5.13 and was also not affected by the heat treatment.

The observed reduction in decay with curing treatment in this study agrees with earlier reports on the efficacy of curing for storage life extension in orange fruits (Lanza et al, 2000). In this investigation, cured fruits stored well beyond 56 days, which is more than the storage period reported for various citruses (Nunes et al., 2007; Kinay et al, 2005). The hardness observed in control fruits and those cured to $1 \%$ weight loss indicate that more water loss from the peel of those fruits resulted into hardened rinds which were not easily penetrated. Fruits cured to as high as 5 and $7 \%$ weight loss already had attained relatively stable weight due to a near equilibrium rate of moisture movement from the fruit surface to the surrounding atmosphere. Evaporation from fruit surfaces was therefore not as fast as those uncured which had higher water content. The vapour pressure deficit existing in the surrounding atmosphere in relation to fruit surface in the control fruits encouraged more water loss from the fruits. The juice content was not affected because the juice was in juice sacs deep inside the albedo from which evaporation could not take place. The delay in peel yellowing observed in cured fruits supports earlier report by Nunes et al. 
(2007) that peel yellowing was slightly delayed by heating 'Valencia' oranges at $40^{\circ} \mathrm{C}$ for $18 \mathrm{~h}$ before storage at $5^{\circ} \mathrm{C}$ for $5 \mathrm{~d}$ and $20^{\circ} \mathrm{C}$ for $7 \mathrm{~d}$.

Results from this study also suggest that curing is superior to hot water dip and chemical treatment. Rodov et al (1995) reported decay reduction to less than $10 \%$ in Kumquat (Fortunella margarita) another citrus by curing at $36^{\circ} \mathrm{C}$ for 72 hours. Palou et al (2001) reported on the efficacy of hot water, sodium carbonate and sodium bicarbonate in reducing postharvest blue and green mould rot of oranges but the efficacy declined by the fifth week of storage at $20^{\circ} \mathrm{C}$. It is significant to note that cured fruits in this study remained healthy throughout the 56 day storage period in the April harvest while there was remarkable reduction in decay in the August harvest. For both batches, curing to $5 \%$ weight loss appeared to be the most effective treatment.
The present result shows that internal quality attributes of fruits were not affected by the treatment throughout the storage period. In addition, the yellowish-green colour of fruits was also preserved by the treatment. Curing to specific weight loss may be more convenient than curing for a specific length of time and is therefore recommended. This seems practicable in developing countries where continuous energy generation usually required when the length of exposure to heat treatment is specified, may not always be possible. Intermittent exposure to hot air until the desired level of weight loss is attained should therefore be a useful guide for practical purposes. The economic advantage of the method should be investigated.

TABLE 1 - Effect of prestorage curing at $37^{\circ} \mathrm{C}$ on decay incidence and rind stoniness of orange fruits during storage at $28^{\mathrm{p}} \mathrm{C}$.

\begin{tabular}{|c|c|c|c|c|c|c|c|c|c|c|c|}
\hline \multicolumn{2}{|c|}{$\begin{array}{l}\text { Period of storage } \\
\text { (days) }\end{array}$} & \multicolumn{5}{|c|}{ April harvest } & \multicolumn{5}{|c|}{ August harvest } \\
\hline \multirow{12}{*}{ Decay (\%) } & & $\mathrm{C}$ & $1 \%$ & $3 \%$ & $5 \%$ & $7 \%$ & $\mathrm{C}$ & $1 \%$ & $3 \%$ & $5 \%$ & $7 \%$ \\
\hline & 0 & 0 & 0 & 0 & 0 & 0 & 0 & 0 & 0 & 0 & 0 \\
\hline & 7 & 0 & 0 & 0 & 0 & 0 & 0 & 0 & 0 & 0 & 0 \\
\hline & 14 & 2.5 & 0 & 0 & 0 & 0 & 90 & 5.6 & 0 & 0 & 0 \\
\hline & 21 & 7.5 & 0 & 0 & 0 & 0 & 100 & 72.2 & 0 & 0 & 0 \\
\hline & 28 & 15 & 0 & 0 & 0 & 0 & 100 & 77.8 & 5.6 & 11.1 & 12.5 \\
\hline & 35 & 22.5 & 0 & 0 & 0 & 0 & 100 & 77.8 & 38.9 & 11.1 & 12.5 \\
\hline & 42 & 22.5 & 0 & 0 & 0 & 0 & 100 & ---- & ---- & ---- & ---- \\
\hline & 49 & 22.5 & 0 & 0 & 0 & 0 & 100 & 88.9 & 61.1 & 16.7 & 2.5 \\
\hline & 56 & 22.5 & 0 & 0 & 0 & 0 & 100 & ---- & ---- & ---- & ---- \\
\hline & 63 & ---- & ---- & ---- & ---- & ---- & 100 & 88.9 & 61.1 & 22.2 & 31.3 \\
\hline & 70 & ---- & ---- & ---- & ---- & ---- & 100 & 88.9 & 61.1 & 22.2 & 31.3 \\
\hline \multirow[t]{11}{*}{ Stoniness(\%) } & 0 & 0 & 0 & 0 & 0 & 0 & 0 & 0 & 0 & 0 & 0 \\
\hline & 7 & 0 & 0 & 0 & 0 & 0 & 0 & 0 & 0 & 0 & 0 \\
\hline & 14 & 0 & 0 & 0 & 0 & 0 & 0 & 0 & 0 & 0 & 0 \\
\hline & 21 & 12.5 & 0 & 0 & 0 & 0 & 0 & 0 & 0 & 0 & 0 \\
\hline & 28 & 17.5 & 0 & 0 & 0 & 0 & 0 & 0 & 0 & 0 & 0 \\
\hline & 35 & 45 & 0 & 0 & 0 & 0 & 0 & 0 & 0 & 0 & 0 \\
\hline & 42 & 45 & 2.5 & 0 & 0 & 0 & 0 & 0 & 0 & 0 & 0 \\
\hline & 49 & 60 & 10 & 0 & 0 & 0 & 0 & 0 & 0 & 0 & 0 \\
\hline & 56 & 67.5 & 10 & 0 & 0 & 0 & 0 & 0 & 0 & 0 & 0 \\
\hline & 63 & ---- & ---- & ---- & ---- & ---- & 0 & 0 & 0 & 0 & 0 \\
\hline & 70 & ---- & ---- & ---- & ---- & ---- & 0 & 5.6 & 0 & 5.6 & 0 \\
\hline
\end{tabular}

$\mathrm{C}=\mathrm{Control}$ (uncured); the $\%$ represent the percentage loss in weight obtained by curing before storage. 
TABLE 2 - Juice content of orange fruits during storage at $28^{\circ} \mathrm{C}$ after hot air curing at $37^{\circ} \mathrm{C}$.

\begin{tabular}{ccccccccc}
\hline $\begin{array}{c}\text { Treatment } \\
\text { (\% weight loss) }\end{array}$ & \multicolumn{7}{c}{ Juice content (ml) / Period of storage (Days) } \\
\hline 0 (Control) & 6 & 7 & 14 & 21 & 28 & 35 & 42 & 56 \\
1 & 68.22 & 66.75 & 63 & 65.75 & 63.22 & $61.38^{*}$ & $59^{*}$ & 64.5 \\
3 & 65 & 65.3 & 66.5 & 63.5 & 69.65 & 70.25 & 75.5 \\
5 & 68.22 & 55.50 & 58.50 & 57.00 & 61.25 & $63.00^{*}$ & $65.75^{*}$ & 66.25 \\
7 & 68.22 & 76.82 & 69.00 & 70.60 & 67.80 & 70.50 & 75.25 & 73.50 \\
LSD ( $\mathrm{p}=0.05)$ & 1.00 & 0.281 & 0.800 & 0.694 & 0.418 & 0.096 & 0.087 & 0.683 \\
\hline
\end{tabular}

Figures followed by * within the column are significantly different from each other $(\mathrm{p}<0.05)$ by Fisher's least Significant Difference.

TABLE 3 - Total soluble solid content of orange fruits during storage at $28^{\circ} \mathrm{C}$ after hot air curing at $37^{\circ} \mathrm{C}$.

\begin{tabular}{ccccccccc}
\hline $\begin{array}{c}\text { Treatment } \\
(\% \text { weight loss })\end{array}$ & \multicolumn{8}{c}{ Total Soluble Solids $\left({ }^{\mathrm{p}}\right.$ Brix $)$ / Period of storage (Days) } \\
\hline 0 (Control) & 0 & 7 & 14 & 21 & 28 & 35 & 42 & 56 \\
1 & 10.23 & 10.00 & $9.52^{*}$ & 10.73 & 10.83 & 12.00 & $11.43^{*}$ & 12.60 \\
3 & 10.60 & 10.02 & 11.43 & $10.03^{*}$ & $9.10^{*}$ & 11.80 & 11.20 & $11.40^{*}$ \\
5 & 10.83 & 10.10 & 10.40 & 11.03 & 11.50 & 10.60 & 11.33 & 11.80 \\
7 & 10.48 & 10.53 & 9.82 & 10.42 & 11.43 & 11.83 & $10.60^{*}$ & 11.80 \\
LSD $(\mathrm{p}=0.05)$ & 10.87 & $11.00^{*}$ & 11.00 & 11.20 & 10.80 & $11.03^{*}$ & 12.00 & 12.62 \\
\hline
\end{tabular}

Figures followed by * within the column are significantly different from each other $(\mathrm{p}<0.05)$ by Fisher's least Significant Difference

TABLE 4 - Titratable acidity of orange fruits during storage at $28^{\circ} \mathrm{C}$ after hot air curing at $37^{\circ} \mathrm{C}$.

\begin{tabular}{ccccccccc}
\hline $\begin{array}{c}\text { Treatment } \\
(\% \text { weight loss })\end{array}$ & \multicolumn{8}{c}{ Titratable acidity (\% Citric acid) / Period of storage (Days). } \\
\hline & 0 & 7 & 14 & 21 & 28 & 35 & 42 & 56 \\
0 (Control) & 1.40 & $1.50^{*}$ & $1.58^{*}$ & $1.60^{*}$ & $1.72^{*}$ & $1.75^{*}$ & $1.80^{*}$ & $1.72^{*}$ \\
1 & 1.45 & 1.41 & 1.46 & 1.48 & 1.52 & 1.50 & 1.51 & 1.50 \\
3 & 1.39 & 1.38 & 1.38 & 1.36 & 1.37 & 1.30 & 1.28 & 1.25 \\
5 & 1.39 & 1.39 & $1.27^{*}$ & 1.37 & $1.29^{*}$ & $1.30^{*}$ & 1.30 & 1.43 \\
7 & 1.41 & 1.36 & 1.35 & $1.31^{*}$ & 1.31 & 1.31 & 1.35 & 1.50 \\
LSD (p=0.05) & 0.023 & 0.003 & 0.004 & 0.003 & 0.003 & 0.002 & 0.002 & 0.003 \\
\hline
\end{tabular}

Figures followed by * within the column are significantly different from each other $(\mathrm{p}<0.05)$ by Fisher's least Significant Difference

TABLE 5 -Firmness of orange fruits during storage at $28^{\circ} \mathrm{C}$ after hot air curing at $37^{\circ} \mathrm{C}$.

\begin{tabular}{lcccccccc}
\hline $\begin{array}{c}\text { Treatment } \\
(\% \text { weight loss })\end{array}$ & \multicolumn{7}{c}{ Firmness (N) / Period of storage (Days) } \\
0 (Control) & 0 & 7 & 14 & 21 & 28 & 35 & 42 & 56 \\
1 & 8.48 & $2.44^{*}$ & $1.84^{*}$ & $2.07^{*}$ & 5.33 & $5.32^{*}$ & $21.36^{*}$ & $81.13^{*}$ \\
3 & 8.48 & $2.71^{*}$ & $2.02^{*}$ & $2.65^{*}$ & $3.84^{*}$ & $6.95^{*}$ & $13.51^{*}$ & $37.47^{*}$ \\
5 & 8.48 & $4.46^{*}$ & $3.47^{*}$ & $3.30^{*}$ & $3.95^{*}$ & $6.91^{*}$ & $6.70^{*}$ & $13.07^{*}$ \\
7 & 8.48 & $8.16^{*}$ & $6.70^{*}$ & $5.99^{*}$ & 6.38 & 8.49 & $8.94^{*}$ & $16.38^{*}$ \\
LSD ( $=0.05)$ & 8.48 & $8.64^{*}$ & $7.97^{*}$ & $8.11^{*}$ & $8.48^{*}$ & $14.09^{*}$ & $9.31^{*}$ & $11.00^{*}$ \\
& 1.00 & 0.00 & 0.00 & 0.00 & 0.047 & 0.066 & 0.00 & 0.00
\end{tabular}

Figures followed by * within the column are significantly different from each other $(\mathrm{p}<0.05)$ by Fisher's least Significant Difference. 


\section{REFERENCES}

AFEK, U.; ORENSTEIN, J..;NURIEL, E. Steam treatment to prevent carrot decay during storage. Crop Protection, Kidlington, v.19, p.639-642, 1999.

BIRLA, S.L; WANG, S; TANG, J.; HALLMAN, G. Improving heating uniformity of fresh fruit in radio frequency treatments for pest control. Postharvest Biology and Technology, Pullman, v.33, n.2, p. 205-217, 2004.

BIRLA, S.L; WANG, S.; TANG, J. Radio frequency heating patterns as influenced by dielectric properties of constituent parts of fruit. St.Joseph: American Society of Agricultural and Biological Engineers, 2006. (Paper 066052).

FALLIK, E; KLEIN, J; GRINBERG, S; LOMANIEC, E; LURIE, S.;LALAZAR, A. Effect of postharvest heat treatment of tomatoes on fruit ripening and decay caused by Botrytis cinerea. Plant Disease, St Paul, v.77, p.985-988, 1993.

HUANG, Y; DEVERALL, B.J.; MORRIS, S.C. Postharvest control of green mould on oranges by a strain of Pseudomonas glathei and enhancement of its biocontrol by heat treatment. Postharvest Biology and Technology, Pullman, v.5, p.129-137, 1995.

ISMAIL, M.; ZHANG, J. Postharvest citrus diseases and their control. Outlooks on Pest Management, Burnham. v.15, p.29-35. 2004.

JACOBI, K.K; WONG, L.S.; GILES, J.E. Effect of hot air disinfestations treatment in combination with simulated air freight conditions on quality of 'Kensington' mango (Mangifera indica Linn.). Australian Journal of Experimental Agriculture, Collingwood, v.36, p.739-745, 1996.

KINAY P; YILDIZ F; SEN F, YILDIZ M.; KARACALI I, Integration of pre - and postharvest treatments to minimize Penicillium decay of Satsuma mandarins. Postharvest Biology and Technology, Pullman, v.37, p.31-36, 2005.

LANZA, C.M; PAGLIARINI, E.; LANZA, G. Study of the shelf-life of cured cv. Tarocco oranges by sensory and physicochemical parameters. Journal of the Science of Food and Agriculture, London, v.80, n.2, p. 241-246, 2000.

NUNES, C; USALL, J; MANSO, T; TORRES, R; OLMO, M.; GARCIA, J.M. Effect of high temperature treatments on growth of Penicillium sp and their development on 'Valencia' Oranges. Food Science and Technology International, New York, v.13, n.1, p.63-68, 2007.

PALOU, L; SMILANICK, J.L; USALL, J.;VINAS, I. Control of postharvest blue and green molds of oranges by hot water, sodium carbonate, and sodium bicarbonate. Plant Disease, St Paul, v.85, n.4, p.371376, 2001.

PLAZA, P; USALL, J., TORRES, R., ABADIAS, M., SMILANICK, J.L.; VINAS, I. The use of sodium carbonate to improve curing treatments against green and blue moulds on citrus fruits. Pest Management Science, Sussex, v.60, n.8, p.815-821, 2004.

RODOV, V; BEN-YEHOSHUA, S; ALBAGLI, R.; FANG, D. Q. Reducing chilling injury and decay of stored citrus fruit by hot water dips. Postharvest Biology and Technology, Pullman, v.5, p.119-127, 1995.

SAPITNITSKAYA, M; MAUL, P; MCCOLLUM, G.T; GUY, C.L; WEISS, B; SAMACH, A.; PORAT, R. Postharvest heat and conditioning treatments activate different molecular responses and prevent chilling injuries on grapefruit. Journal of Experimental Botany, Oxford, v.57, n.12, p.2943-2953, 2006.

SCHIRRA, M; AGABBIO; M; D'HALLEWIN, G; PALA, M; RUGGIU, R Response of Tarocco oranges to picking date, postharvest hot water dips, and chilling storage temperature. Journal of Agricultural and Food Chemistry, Easton, v.45, p.3216-3220, 1997.

SMILANICK, J.L; MANSOUR, M.F.; SORENSON, D. Pre and post harvest treatments to control green mould of citrus fruit during ethylene degreening. Plant Disease, St Paul, v.90, n.1, p. 89-96, 2006. 